\title{
THE IMPLEMENTATION OF GOVERNMENT POLICY IN EMPOWERING BUSINESS AND «IRA-MASI» GROUP OF GIFT NILE TILAPIA (OREOCHROMIS SP.) FARMERS IN SUCO COM, EAST TIMOR
}

\author{
Valensa Jorge DaKosta \\ Postgraduate Program, Faculty of Fisheries and Marine Sciences, \\ University of Brawijaya \& Polytechnic Institute of Betano, Indonesia \\ E-mail: jorgevalensa@gmail.com
}

\begin{abstract}
Policy implementation is widely seen as the application of the legislation in which various actors, organizations, procedures, and techniques collaborate to implement policies in order to achieve policy goals or programs comprehended as a process, an output, and an impact (outcome). This study aims to identify and analyze the implementation of government policy in empowering the business and group of fish farmers, recognize the constraints faced by group of fish farmers, establish empowerment strategies that can be developed in empowering business and group of fish farmers, and determine the role of the government in empowering the wealth of fish farmer groups. This research was conducted in Com Village, Lautem Moro Subdistrict, Lautem District, East Timor, from December 15th, 2017, to February 5th, 2018. This research was conducted using qualitative descriptive method. Data collection used in this study was the primary and secondary data obtained using observation, interview, and documentation techniques.
\end{abstract}

\section{KEY WORDS}

Policy, implementation, government, empowerment, fish farmers group.

The world development urges the improvement of each country in various aspects of social life which certainly cannot be separated from every policy taken by the highest apparatus in a country. Various supporting factors in the success of a state concept such as the democracy concept require the society to think about political actions. It is clear that as a social creature, it is not advantageous for the society to sit quietly while all decisions concerning society are made by a ruler they cannot control or direct. Active participation in improving a habitual, society, or nation existence is an important part of the development of the social character.

There are at least two English terms similar to the village concept, i.e. rural and village. Rural areas involve a number of villages in which the characteristics of the society include farmers as the most occupation, living in a family atmosphere, and other social characteristics identical to rural areas (Krisdyatmiko, 2002). Meanwhile, village development is a further development strategy of the village development strategy. In the village development, intensive efforts are carried out with the aim and tendency to focus on particular groups and regions through the delivery of services, assistance, and information to the villagers (Pootstchi, 1986).

This strategy sees development as a unified process with the economic aspect as a part of it. In the process, in addition to the economic aspects, there are social, political, cultural, psychological, and technical aspects mutually interacted, correlated, and maintained. The map of East Timorese lives based on the results of the 2015 population census shows that of $1,183,643$ people, $66.6 \%$ are farmers in 2,225 communities, 442 villages, 65 subdistricts, and 13 districts (National Statistics Directorate of East Timor, 2015 Census).

In Lautem District, especially Lautem Moro Subdistrict, many people still feel the powerlessness, especially fish farmers whose daily life only relies on the results of fish farming. This is also affected by the growing population in Lautem Moro Subdistrict based on the results of 2015 population census of 20,410 people in the area of approximately 380.17 
$\mathrm{km}^{2}$. With the increasing number of people from year to year, the level of competition in people's lives is higher and the job field is more difficult to find. As a result, the society, especially at the rural level, can only sustain life in agriculture, such as rice fields, fields, and fish farmings.

The Government, in the $6^{\text {th }}$ Government Cabinet under the leadership of Prime Minister Rui Maria de Araujo, has a strategy of village community development, especially farmers, through the Ministry of Agriculture and Fisheries (Ministerio Agricultura e Pescas). They provide free fish farming facilities for farmer groups to improve the farmer wealth and to provide empowerment.

\section{MATERIALS AND METHODS OF RESEARCH}

This research was conducted using qualitative descriptive method. According to Kirk and Miller, qualitative research is a practice in social science that relies on observation of people in their own areas and relates to their language and terminology. Thus, qualitative descriptive research is an effort to disclose the event or the state of the research subject or object and solve the problems faced at this time based on observable facts or actual circumstances. Referring to that objective, the focus of the research entitled "The implementation of Government policy in empowering the business and group of Gift Nile tilapia (Oreochromis sp) farmers in Suco Com, East Timor" is to investigate the government policy implementation program. This research was conducted in Com Village, Lautem Moro Subdistrict, Lautem District, East Timor.

The research was conducted from December $15^{\text {th }}, 2017$, to February $5^{\text {th }}, 2018$. The reasons for the research site selection by the researcher were because the selected location was the location and target group of the Government in the policy implementation program.

Selection Techniques of Informant or Research Subject. In determining the informants or research subjects, the researcher used a combination of Snow Ball and purposive techniques. The purposive sampling technique was used in accordance with the purpose of the research. The sample units contacted were tailored to the specific criteria set by the research objectives (Nawawi, 2005).

According to Black and Champion (1999), purposive sampling is one way the researchers take to ensure that certain elements are inserted into the sample.

Data collection technique. Data collection techniques the researcher applied in this study were as follows: Observation; Interview; Documentation.

Data analysis technique. Data analysis techniques the researcher employed in this study were: Data reduction; Data presentation; Conclusion.

\section{RESULTS AND DISCUSSION}

Lautem District consists of 5 subdistricts, 34 villages, and 151 communities with an area of $+1,813.12 \mathrm{~km}^{2}$. It is bordered by Australia to the south, the Republic of Indonesia to the east and north, and Baucau and Viqueque District to the west. The population based on 2017 data source is 84,533 people, while the languages as the unifying tool in Lautem District are Fataluku, Makasae, Makalero, and lowaa. The fish farmer group (Ira-Masi) is located in Muaposu Community, Com Village, Lautem Moro Subdistrict, Lautem District. It is bordered by Kisar Island to the north, Bauro Village to the south, Mehara Village to the east, and Parlamento Village to the west. Muaposu Community as the research location is located on the east side of Com Village. The population of Muaposu Community is spread on the shores of Com beach in the plateau located $542 \mathrm{~m}$. above the sea level. Muaposu Community as the location of the fish farmer (Ira-Masi) group is not the only community having a farmer group. There are many more other farmer groups in Com Village. Those groups of farmers in Com Village are registered at the Ministry of Agriculture and Fisheries (MAP) of Lautem to get free fish farming facilities.

Table 1 presents several groups of fish farmers located in Muaposu Community, Com Village, Lautem City. 
Table 1 - Groups of Fish Farmers in Com Village

\begin{tabular}{|c|c|c|c|c|c|c|c|c|c|}
\hline \multirow[t]{2}{*}{ No } & \multirow{2}{*}{$\begin{array}{c}\text { Name of group } \\
\text { leader }\end{array}$} & \multicolumn{2}{|c|}{ Fish species } & \multirow{2}{*}{$\begin{array}{l}\text { Location } \\
\text { of farming }\end{array}$} & \multirow{2}{*}{$\begin{array}{l}\text { Number } \\
\text { of Ponds }\end{array}$} & \multicolumn{2}{|c|}{$\begin{array}{l}\text { Number } \\
\text { of group } \\
\text { members }\end{array}$} & \multirow{2}{*}{$\begin{array}{l}\text { The width of } \\
\text { the ponds }\end{array}$} & \multirow{2}{*}{$\begin{array}{c}\text { Acreage } \\
(\mathrm{Ha})\end{array}$} \\
\hline & & $\begin{array}{c}\text { Nile } \\
\text { tilapia } \\
\end{array}$ & Goldfish & & & $\mathrm{M}$ & $F$ & & \\
\hline 1. & Ermundo da cruz & $\begin{array}{c}\text { Nile } \\
\text { tilapia }\end{array}$ & - & Muapuso & 4 units & 5 & 2 & $\begin{array}{l}-20 \times 20 m^{2}=2 \\
-10 \times 10 m^{2}=2\end{array}$ & $1000 \mathrm{~m}^{2}$ \\
\hline 2. & $\begin{array}{c}\text { Armindo dos } \\
\text { santos }\end{array}$ & $\begin{array}{c}\text { Nile } \\
\text { tilapia } \\
\end{array}$ & - & Muapuso & 2 units & 6 & 3 & $7 \times 8 m^{2}=2$ & $112 \mathrm{~m}^{2}$ \\
\hline 3. & $\begin{array}{l}\text { Hermenegildo } \\
\text { M.Xavier }\end{array}$ & $\begin{array}{l}\text { Gift Nile } \\
\text { tilapia }\end{array}$ & - & Muapuso & 10 units & 5 & 5 & $7 \times 20=10$ & $1400 \mathrm{~m}^{2}$ \\
\hline
\end{tabular}

Source: Ministry of Agriculture and Fisheries of Lautem City.

The establishment of the Nile tilapia farmer group (Ira-Masi) began in 2016 to respond to the implementation of Government policy through the Ministry of Agriculture and Fisheries in the empowerment program of fish farmer group and productive land utilization. The farming land is the private property of Mr. Hermenegildo who is also the head of the farming group. With the approval of the land, the Government fully assists the program. The assistance provided by the Ministry of Agriculture and Fisheries is providing free support to each farmer group, especially the fish farmer group (Ira-Masi), for empowering the farmer's community. This can be realized at the beginning of the Parliamentary Majority Alliance governance in 2007 through the statement of Ministry of Agriculture and Fisheries: Strong Agriculture, Strong State (Agrikultura Forte, Nasaun Forte). The statement is based on the idea that the agricultural sector plays an important role as the basic foundation in the national economic development in East Timor. Table 2 presents the organizational structure of the fish farmer group (Ira-Masi).

Table 2 - Members of the Gift Nile tilapia farmer group (Ira-Masi)

\begin{tabular}{clccc}
\hline No. & Name & Gender & Age & Information \\
\hline 1. & Hermenegildo Maria Xavier & $\mathrm{M}$ & 43 & Group leader \\
2. & Luis Maria Xavier & $\mathrm{M}$ & 70 & Member \\
3. & Orlando Marques & $\mathrm{M}$ & 65 & Member \\
4. & Alcino Lopes & $\mathrm{M}$ & 45 & Member \\
5. & Olderico Marques & $\mathrm{M}$ & 35 & Member \\
6. & Alcina Lopes & $\mathrm{F}$ & 54 & Member \\
7. & Tereza Neves & $\mathrm{F}$ & 38 & Member \\
8. & Fransisca Neves & $\mathrm{F}$ & 16 & Member \\
9. & Elita Lopes & $\mathrm{F}$ & 44 & Member \\
10. & Rozinha Lopes & $\mathrm{F}$ & 68 & Member \\
\hline
\end{tabular}

This research results can strategically be used to formulate Government policy in empowering the business and group of fish farmers in Com Village. The results were obtained through a logical framework using SWOT analysis. This analysis is based on the logic that maximizes Strength and Opportunity and simultaneously minimizes Weakness and Threat (Rangkuti, 2000). The identification result of Strategic Internal Factors Analysis Summary (IFAS) obtains six factors consisting of three strengths and three weaknesses for the empowerment policy of business and group (Ira-Masi) of fish farmers in Muaposu Community, Com Village as the Government empowerment target area. Strength aspects consist of readiness of land and members of farmer groups, availability of good and uncontaminated water source, and togetherness of the farmer group members. The weaknesses consist of the lack of group members' knowledge about fish farming business, the exposed farming land, and the lack of fish farming marketing. Internal factors becoming the main strength is the readiness of land and potential water source that can serve as the location of government policy implementation targets in empowering the business and group of fish farmers in Muaposu Community, Com Village with a total of relative internal strength weight value of 0.418 based on the identification of Strategic Internal Factors Analysis Summary (IFAS). Whereas, the main weaknesses are the lack of group members' 
knowledge about fish farming business and the exposed farming area causing it to be very vulnerable for the farming result. The relative weakness weight value based on the identification of Strategic Internal Factors Analysis Summary (IFAS) analysis is 0.993. Table 3 presents the identification results.

Table 3 - Identification Results of Strategic Internal Factors Analysis Summary (IFAS)

\begin{tabular}{|c|c|c|c|c|c|}
\hline No. & \multicolumn{2}{|r|}{ Aspect } & \multirow{2}{*}{ Weight } & \multirow{2}{*}{ Rating } & \multirow{2}{*}{ Score } \\
\hline $\mathrm{A}$ & & Strength Factor & & & \\
\hline (1) & \multicolumn{2}{|r|}{$(2)$} & (3) & (4) & (5) \\
\hline 1 & S1 & A fertile area with biodiversity & 0.075 & 19 & 1.425 \\
\hline 2 & S2 & The uncontaminated condition of the water source & 0.079 & 20 & 1.58 \\
\hline 3 & S3 & Availability of workers & 0.063 & 16 & 1.008 \\
\hline 4 & S4 & The high market demand for local fish & 0.063 & 16 & 1,008 \\
\hline 5 & S5 & Awareness of group members & 0.059 & 15 & 0.885 \\
\hline 6 & S6 & The readiness of the Government to help & 0.079 & 20 & 1.58 \\
\hline & Total of strength factors & 0.418 & \multirow[b]{2}{*}{-} & \multirow{2}{*}{7.486} \\
\hline \multicolumn{2}{|c|}{$\mathrm{B}$} & Weakness Factor & & & \\
\hline 1 & W1 & Low level of members' education and skills & 0.079 & 20 & 1.58 \\
\hline 2 & W2 & Minimal group organization & 0.059 & 15 & 0.885 \\
\hline 3 & W3 & No post-harvest practice before being marketed & 0.059 & 15 & 0.885 \\
\hline 4 & $\overline{\mathrm{W} 4}$ & No technology utilization & 0.051 & 13 & 0.663 \\
\hline 5 & W5 & No funds from government/private institutions & 0.059 & 15 & 0.885 \\
\hline 6 & W6 & The exposed farming area & 0.079 & 20 & 1.58 \\
\hline 7 & W7 & Lack of government role in controlling farming business & 0.059 & 15 & 0.885 \\
\hline 8 & W8 & Lack of results marketing management & 0.063 & 16 & 1.008 \\
\hline 9 & W9 & Productive only in certain seasons & 0.067 & 17 & 1.139 \\
\hline \multirow{2}{*}{\multicolumn{2}{|c|}{ - }} & Total of weakness factors & 0.575 & \multirow{2}{*}{-} & 9.51 \\
\hline & & Total internal factors & 0.993 & & \\
\hline
\end{tabular}

Source: Research Results.

The most likely threat is the security of farming area because the farming area is very exposed and far from the society settlement, farming area damage due to lack of care from the members of fish farmer group (Ira-Masi), and less stable Government policy due to political interest. The total weight for the opportunity factor of this analysis is 0.567 with a score of 10.789 , while the threat with weight value of 0.511 , the score is 8.94 . Table 4 presents the identification result.

Table 4 - Identification Result of Strategic External Factors Summary Analysis (EFAS)

\begin{tabular}{|l|l|l|l|l|l|}
\hline No. & Aspect & Weight & Rating & Score \\
\hline A & \multicolumn{2}{|l|}{ Opportunity Factor } & & & \\
\hline$(1)$ & $(2)$ & $(3)$ & $(4)$ & $(5)$ & $(6)$ \\
\hline 1 & O1 & Benefits of government policies implementation & 0.085 & 20 & 1.7 \\
\hline 2 & O2 & High selling value of gift Nile Tilapia commodity & 0.081 & 19 & 1.539 \\
\hline 3 & O3 & Increased members' income & 0.085 & 20 & 1.7 \\
\hline 4 & O4 & Contribution to the economic development program & 0.081 & 19 & 1.539 \\
\hline 5 & O5 & The development of gift Nile tilapia business & 0.077 & 18 & 1.386 \\
\hline 6 & O6 & Potential for tourism objects & 0.077 & 18 & 1.386 \\
\hline 7 & O7 & Potential for local fish resource management & 0.081 & 19 & 1.539 \\
\hline \multicolumn{2}{|l|}{} & Total of opportunity factors & 0.567 & & 10.789 \\
\hline B & Threat Factor & & & \\
\hline 1 & T1 & Lack of human resources capacity & 0.064 & 15 & 0.96 \\
\hline 2 & T2 & Less control of water sources & 0.064 & 15 & 0.96 \\
\hline 3 & T3 & Limited feed for gift Nile tilapia & 0.064 & 15 & 0.96 \\
\hline 4 & T4 & Irregular feeding & 0.085 & 20 & 1.7 \\
\hline 5 & T5 & Uncontrolled water parameters & 0.085 & 20 & 1.7 \\
\hline 6 & T6 & Open farming area & 0.085 & 20 & 1.7 \\
\hline 7 & T7 & Minimal togetherness of group members & 0.064 & 15 & 0.96 \\
\hline \multicolumn{2}{|l|}{} & Total of threat factors & 0.511 & & 8.94 \\
\cline { 2 - 6 } & Total of external factors & 1.078 & & \\
\hline Difference in total of opportunity - total of threat = O - T = y: 1.849 & & & \\
\hline
\end{tabular}

Source: Research Results. 
From the results of observations, the strategic factors in the form of figures were obtained which were then inventoried into the Strategic Internal Factor Analysis Summary (IFAS) Matrix and Strategic External Factors Analysis Summary (EFAS) Matrix, which can be seen in the following table.

Table 5 - Results of IFAS and EFAS matrix

\begin{tabular}{|c|c|c|}
\hline No. & Total of Internal Factor Scores & Total of External Factor Scores \\
\hline 1. & $\mathrm{~S}=7.486$ & $\mathrm{O}=10.789$ \\
\hline 2. & $\mathrm{~W}=9.51$ & $\mathrm{~T}=8.94$ \\
\hline \multirow{2}{*}{-} & Difference between score S $-\mathrm{W}=\mathrm{x}$ & Difference between score O $-\mathrm{T}=\mathrm{y}$ \\
\cline { 2 - 3 } & $\mathrm{X}=-2.024$ & $\mathrm{Y}=1.849$ \\
\hline
\end{tabular}

Source: Research Results.

Based on the results of scoring analysis of internal and external factors, the axis $x=-$ 2.024 and $y$-axis $=1.849$ were obtained.

Furthermore, the results of this analysis are presented in the quadrant form of each SWOT quadrant factor by Pearce \& Robinson (1998) which can be seen in the following figure.

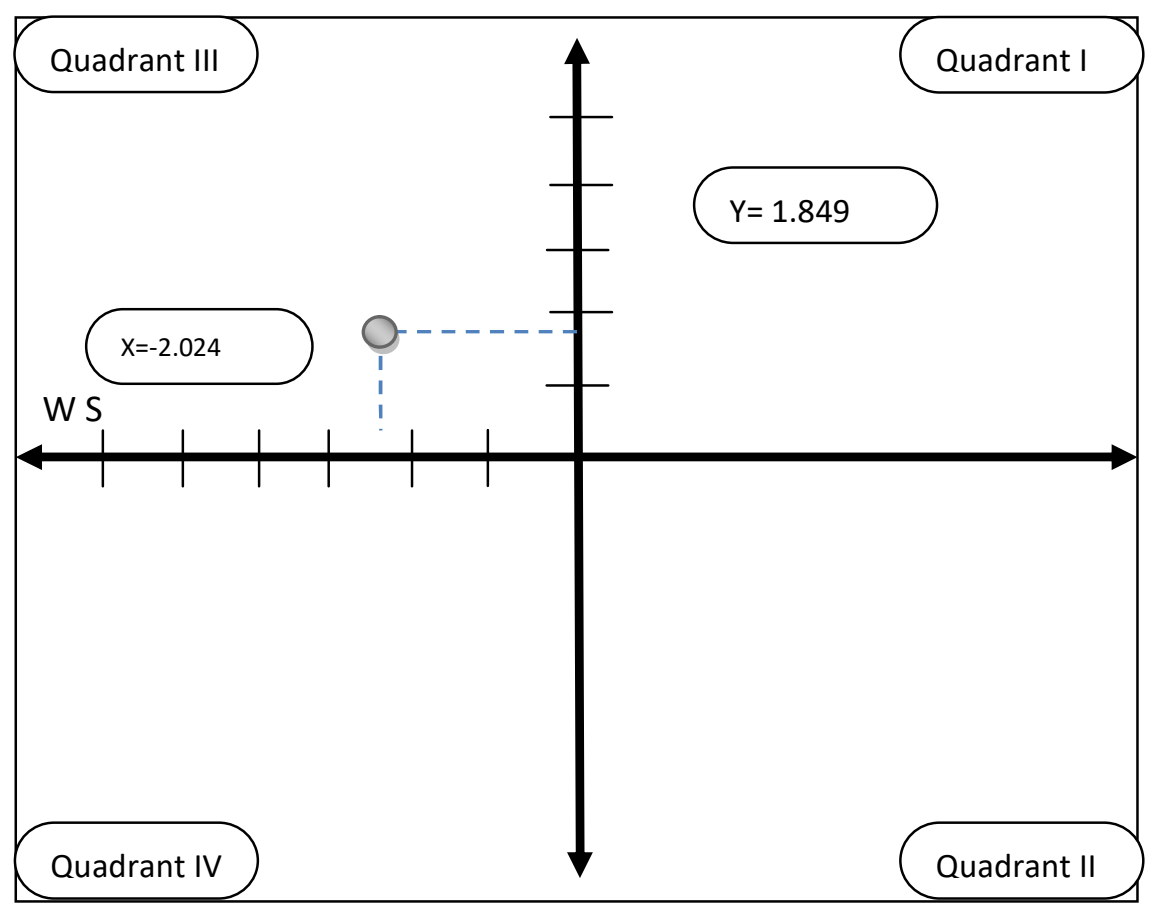

Figure 1 - Quadrant of SWOT analysis Results

The figure above shows that the $x$-axis and $y$-axis has a negative and positive value, so the position of the organization on the diagram lies in quadrant III. Thus, this position signifies a weak but potential organization. The recommendation given is a change of strategy which means that farmers are advised to change the previous strategy because the old strategy is difficult to acquire the existing opportunities and to improve the farmer operation.

\section{CONCLUSION}

The conclusions of this research based on the implementation of Government policy through the Ministry of Agriculture and Fisheries No.17/GM-MAP/2015 on the identification of potential areas for the empowerment of farmer groups, especially to members and group IraMasi of fish farmers in Muaposu Community, Com Village, are the following: 
- The Government, especially the Ministry of Agriculture and Fisheries, with all the strength is committed to help the society, especially fish farmer groups in business and group empowerment.

- Empowerment strategy undertaken in empowering businesses and fish farmer group Ira-Masi is the awareness of the mindset.

- Strengthening the capacity of farmer group "Ira-Masi" members by various activities such as trainings, workshops, seminars, farming meetings, and so on.

\section{REFERENCES}

1. Abdul Wahab, Solichin. 2008. Analisis Kebijakan dari formulasi ke implementasi kebijakan negara. Jakarta: PT. Bumi Aksara.

2. Adi, Isbandi Rukminto.2008. Intervensi Komunitas Pengembangan Masyarakat. Sebagai upaya Pemberdayaan Masyarakat. Jakarta: Raja Grafindo Persada.

3. Anderson, James E. (1979). Public Policy Making. New York: Holt, Rinehard and Winston, 2nd ed.

4. Amri, K. dan Khairuman. 2002. Buku Pintar Budidaya 15 Ikan Konsumsi. Agromedia. Jakarta.

5. Baharuddin dan wahyuni, N, (2007). Teori Belajar dan Pembelajaran. Yogyakarta: ArRuzz Media Group.

6. Basrowi dan Suwandi. 2008. Memahami Penelitian Kualitatif. Jakarta: RINEKA CIPTA.

7. Benis and Mische, 1999, Paparan teori tentang pemberdayaan.

8. Black, J.A. and D.J. Champion, 1999. Metode dan Masalah Penelitian Sosial. Cetakan kedua. P.T. Refika Aditama. Bandung.

9. Dwidjowijoto dan Wrihatnolo, 2007. Manajemen Pemberdayaan: Sebuah Pengantar dan Panduan untuk Pemberdayaan Masyarakat. Jakarta: PT. Elex Media Komputindo.

10. Dye, R. Thomas, 1978, Understanding Public Policy, Prentice Hall. inc, New York.

11. Hasan M.I. 2002. Pokok-Pokok Materi Metodologi Penelitian dan Aplikasinya. Ghalia Indonesia. Jakarta.

12. Heywood, Andrew, 2002. Politics, Palgrave, New York.

13. Hulme dan Turner, 1996:63, Paparan teori tentang pemberdayaan.

14. Ikbal, Hasbi, Implementasi Kebijakan program bantuan langsung tunai 2008 di Kabupaten Kudus. Tesis Master, Universitas Diponegoro, 2008.

15. Kartasasmita, 1996, Paparan teori tentang pemberdayaan.

16. Krisdyatmiko, 2002, Rekonstruksi Pemahaman Tentang Desa. Penerbit Aditya Media Yogyakarta.

17. 2002,Pemerintah daerah,Undang-Undang Dasar Republik Demokratik Timor Leste, pasal 72.

18. 2010, Sensus Penduduk,Badan Statistik Nasional Timor Leste.

19. Moleong, L.J., 2000. Metodologi Penelitian Kualitatif, Remaja Rosdakarya, Bandung.

20. Moleong.Lexy J.2007.Metodologi Penelitian Kualitatif. Edisi Revisi. Bandung: Penerbit PT Remaja Rosdakarya offset.

21. Moleong,L.J. 2010. Metodologi Penelitian Kualitatif. Bandung: Remaja Rosda Karya.

22. Moeljarto dan Pranarka, 1996, Paparan teori tentang pemberdayaan.

23. Muliawan,J.U. (2008). Manajemen Home Industri Peluang Usaha di tengah krisis. Yogyakarta: Banyu Media.

24. Nawawi, H. 2005. Metode Penelitian Bidang Sosial. Gadjah Mada University Press. Yogyakarta.

25. Nugroho, D. Riant, 2003, Kebijakan Publik: Formulasi, Implementasi dan Evaluasi, Elex Media Computindo, Gramedia, Jakarta.

26. Nugroho, Heru. 2001. Negara Pasar dan Keadilan Sosial. Pustaka Pelajar. Yogyakarta.

27. Pootstchi, Iraj, 1986, Rural Development and The Developing Countries, The Alger Press Ltd, Oshawa. 
28. Rangkuti, F. 2009. Analisis SWOT Teknik membedah Kasus Bisnis. Reorientasi konsep Perencanaan Strategi untuk Menghadapi abad 21. Penerbit PT. Gramedia Pustaka Utama. Jakarta. Cetakan keenam belas.

29. Rangkuti, F. 2000. Analisis SWOT Teknik Membedah Kasus Bisnis. PT. Gramedia Pusataka Utama. Jakarta. $86 \mathrm{hlm}$.

30. Ranney, Austin, 1996. Governing: An Introduction to politican science, New Jersey: Prentice-Hall International.

31. Satori, Djam'an dan Komariah, Aan. 2009. Metodologi Penelitian Kualitatif. Bandung: ALFABETA.

32. Satori, Djam'an dan Komariah, Aan. 2012. Metodologi Penelitian Kualitatif. Bandung: ALFABETA.

33. Sebatier, Paul and Daniel Mazmanian, Kaplah, Saccuzzo (1980), The Implementation of Public Policy A Frame Work at Analysis Policy Studies, journal 8

34. Subarsono. (2008). Analisis Kebijakan Publik. Yogyakarta: Pustaka Pelajar.

35. Soetomo, 2010. Strategi-Strategi Pembangunan Masyarakat. Pustaka Pelajar. Yogyakarta.

36. Sugiyono, 2008. Metode Penelitian Kuantitatif, Kualitatif dan R\&D. Bandung: ALFABETA.

37. Sugiyono, 2012. Memahami Penelitian Kualitatif. Bandung: ALFABETA.

38. Sumodiningrat, Gunawan.1999, Pemberdayaan Masyarakat dan Jaring pengaman sosial, Jakarta. Gramedia Pustaka Utama.

39. Sunggono, Bambang. (1994) Hukum dan Kebijakan Publik. Jakarta. Sinar Grafika.

40. Widjaja, 2003. Otonomi desa merupakan otonomi yang asli, bulat, dan utuh. Rajawali Press, Jakarta.

41. Winarno, Budi (2002). Teori dan Proses Kebijakan Publik, Yogyakarta: Media Presindo.

42. Van Meter, Donalds and Carl E. Van Horn (1975). " The Policy Implementation Process: A Conceptual Framework”. Administration and Society, Vol.6 No.4 February. 